\title{
Stanje i perspektiva proizvodnje žitarica i uljarica u Republici Hrvatskoj
}

\section{Sažetak}

Poljoprivredna proizvodnja u Hrvatskoj, općenito, ima važan značaj pri čemu biljna proizvodnja čini više od 50\% ukupne poljoprivredne bruto proizvodnje. Najveću ulogu imaju žitarice i uljarice čija proizvodnja dominira u Panonskoj regiji s naglaskom na njen istočni dio. Cilj ovog rada je prikazati zasijane površine, ostvarenu proizvodnju i vanjskotrgovinsku razmjenu kukuruza, pšenice, ječma, soje, suncokreta i uljane repice tijekom petnaestogodišnjeg razdoblja (2003. - 2017.) u Hrvatskoj. Od ukupnih obradivih površina u analiziranom razdobljužitarice (kukuruz, pšenica iječam) zauzimaju oko $60 \%$ obradivih površina, auljarice (soja, suncokret $i$ uljana repica) oko $13 \%$. Analizom podataka utvrđen je trend smanjenja površina pod žitaricama, naročito kukuruza, dok su uljarice pokazale trend rasta pri čemu su površine soje iuljane repice u zadnje tri godine gotovo udvostručene. Pristupanje Republike Hrvatske jedinstvenom tržištu Europske unije pozitivno je utjecalo na povećanje neto izvoza žitarica i uljarica. Prosječni volumen neto izvoza žitarica i uljarica za pet godina članstva u EU se više nego utrostručio u odnosu na prosjek predpristupnog perioda promatranog od 2003. do 2013. godine. Domaće cijene žitarica i uljarica prate trendove cijena na jedinstvenom tržištu uz stabilan razvoj nakon ulaska Hrvatske u Europsku uniju.

Ključne riječi: poljoprivredne površine, žitarice, uljarice, cijene, neto izvoz

\section{Uvod}

Poljoprivreda je strateška gospodarska grana u Republici Hrvatskoj. U ukupnom bruto društvenom proizvodu ostvaruje 3,5\% vrijednosti, dok u strukturi ukupne poljoprivredne bruto proizvodnje biljna proizvodnja čini $54,1 \%$ (DZS, 2017.). Prema istim izvorima od ukupne površine kopna u Hrvatskoj se u promatranom razdoblju (2003. - 2017.) u poljoprivredne svrhe koristilo 1.350 .151 ha ili $25,2 \%$. Od navedenog, u istom razdoblju, najveće površine zauzimaju oranice i vrtovi $(63,7 \%)$ te trajni travnjaci $(30,1 \%)$ dok su voćnjaci, vinogradi, maslinici, povrtnjaci, košaračka vrba i božićna drvca te rasadnici ukupno zastupljeni na svega $6,0 \%$ korištenih poljoprivrednih površina (Statistički ljetopis, 2018.). Uzgoj žitarica i uljarica se uglavnom odvija u Panonskoj regiji koja obuhvaća oko 55\% državnog teritorija i koju prema Köppenu karakterizira umjereno topla i vlažna klima (Šegota i Filipčić, 2003.). U analiziranom periodu žitarice su u prosjeku zastupljene na $59 \%$ obradivih površina, dok najznačajnije uljarice (soja, suncokret i uljana repica) zauzimaju oko $13 \%$ površina. Općenito, istočni dio Hrvatske ili tzv. „žitnica Hrvatske“ je u pogledu zastupljenosti ratarskih kultura najznačajnija. Prema Matić i sur. (2015.) u ovoj podregiji proizvodi se $75 \%$ od ukupne proizvodnje pšenice u $\mathrm{RH}, 60 \%$ ječma, oko $50 \%$ kukuruza, oko $90 \%$ soje i šećerne repe, a suncokreta $100 \%$. Husnjak i Bensa (2018.) navode kako je u Istočnoj podregiji ukupno 441.540 ha poljoprivrednog zemljišta, što čini $73 \%$ ukupne površine ove podregije. Isti autori ističu kako znatnim dijelom ovo područje karakteriziraju tla izuzetno visoke plodnosti (černozem na praporu), iako najveće površine zauzimaju močvarno glejna tla i lesivirana tla, nešto skromnijih proizvodnih potencijala. Nešto zapadnije, tj. na području

doc.dr.sc. Dario Iljkić, David Kranjac, mag.ing.agr., doc.dr.sc. Vladimir Zebec, dr.sc. Ivana Varga, prof.dr.sc. Mirta Rastija,

prof.dr.sc. Manda Antunović, prof.dr.sc Vlado Kovačević, Sveučilište Josipa Jurja Strossmayera u Osijeku,

Fakultet agrobiotehnickih znanosti Osijek, Vladimira Preloga 1, 31000 Osijek, Hrvatska

Autor za korespondenciju:diljkic@fazos.hr 
središnje panonske podregije dominiraju hidromorfna i semiterestrička tla (močvarno glejno, pseudoglej na zaravni i obronačni, pseudoglej-glej, ritska crnica).

Cilj rada bio je prikazati stanje zastupljenosti i proizvodnje najznačajnih šest zrnatih ratarskih usjeva u Republici Hrvatskoj tijekom zadnjeg petnaestogodišnjeg razdoblja od 2003. do 2017. s naglaskom na vanjskotrgovinsku bilancu i cijene navedenih kultura.

\section{Materijali i metode}

U radu su korišteni podatci iz Statističkog ljetopisa Republike Hrvatske Državnog zavoda za statistiku iz 2008. i 2018. u pogledu podjele zasijanih poljoprivrednih površina, ukupne proizvodnje i ostvarenih prinosa šest najzastupljenijih žitarica i uljarica u Hrvatskoj (kukuruz, pšenica, ječam, soja, suncokret i uljana repica). Analizirano je razdoblje od posljednih petnaest godina koje je dovoljno za uočavanje kretanja analiziranih parametara, a obuhvaća razdoblje prije i nakon ulaska Hrvatske u Europsku uniju. Korišteni su podatci Statističkog ureda Europske unije EUROSTAT za prikaz prosječnih proizvođačkih cijena i neto izvoza žitarica i uljarica čiji izračun je dobiven kada se od ukupnog iznosa izvoza (t) oduzme ukupan uvoz (t). Također, izračunati su trendovi ukupnog neto izvoza svih analiziranih kultura.

\section{Rezultati i rasprava}

Površine i proizvodnja žitarica i uljarica u razdoblju od 2003. do 2017. godine

U promatranom petnaestogodišnjem razdoblju uočen je pad proizvodnih površina žitarica, dok proteinski i uljni usjevi imaju blagu tendenciju rasta naročito zadnjih godina. Prema korištenim površinama $\mathrm{u}$ istom razdoblju kukuruz je najdominantnija ratarska kultura u $\mathrm{RH}$, odnosno žitarica. Prosječno se uzgajao na 288.727 ha uz određena variranja između godina. Najveće zasijane površine od 318.973 ha su bile 2005. nakon čega su površine pod kukuruzom u stalnom opadanju pri čemu je 2017. bilo zasijano gotovo 42.000 ha manje od prosjeka (Graf 1.). lako ima više razloga opadanja površina pod kukuruzom najvažniji su rentabilnost proizvodnje i izuzetno niski prinosi u ekstremno nepovoljnim godinama za uzgoj kukuruza. Treba napomenuti kako se zasijane površine odnose na kukuruz za proizvodnju suhog zrna dok se istovremeno u Hrvatskoj u prosjeku uzgaja još i oko 30000 ha silažnog kukuruza. U Hrvatskoj se prosječno proizvelo oko 1,86 milijuna tona zrna kukuruza uz variranja od 1,28 milijuna tona u 2003. do preko 2,5 milijuna tona u 2008. (Graf 1.). lako se Hrvatska nalazi u optimalnom uzgojnom području za proizvodnju kukuruza od $15-45^{\circ}$ sjeverne geografske širine, ima relativno plodna tla i velik izbor visokoprinosnih hibrida, razlike u proizvodnji između godina mogu biti i preko $50 \%$. Glavni razlozi niskih prinosa zrna su nedovoljne količine oborina tijekom vegetacije, neravnomjerna distribucija oborina i ekstremno visoke temperature naročito u fenološkim fazama cvatnje i oplodnje. Tako su u promatranom razdoblju zabilježene tri vrlo nepovoljne godine (2003., 2007. i 2012.) s izuzetno niskom proizvodnjom zrna kukuruza od prosječno 1,33 milijuna tona. Prema podatcima Državnog zavoda za statistiku (2018.) prosječni prinos kukuruza u Hrvatskoj u promatranom razdoblju (2003.-2017.) je iznosio 6,5 t ha-1 ${ }^{-1}$ što je relativno nizak prinos zrna s obzirom na genetički potencijal tog usjeva od preko $20 \mathrm{t} \mathrm{ha}^{-1}$. Najmanji prosječni prinosi od svega 4,5 t ha-1 su ostvareni u vremenski vrlo nepovoljnim uvjetima (sušne godine), kakvi su bili u vegetaciji 2003., 2007. i 2012. godine, dok su u 2008. i 2014. godini, uz povoljan raspored oborina, prosječni prinosi zrna kukuruza bili čak $8,1 \mathrm{t} \mathrm{ha}^{-1}$ odnosno $80 \%$ viši. 


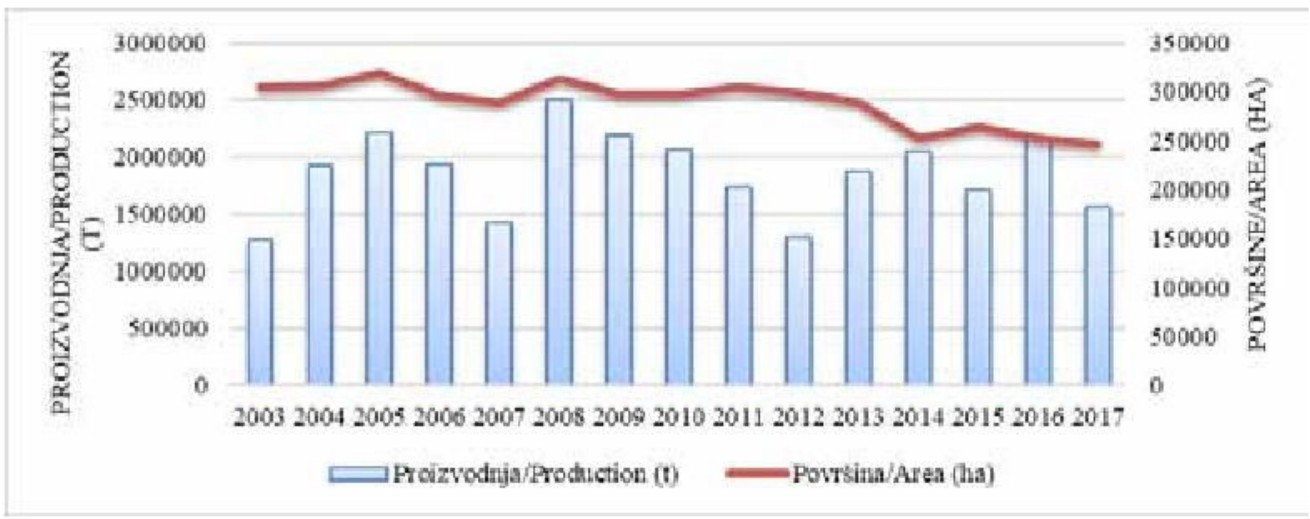

Graf 1. Požnjevene površine (ha) i proizvodnja (t) kukuruza u Hrvatskoj od 2003. do 2017. Graph 1. Harvested area (ha) and maize production in Croatia from 2003 to 2017 Izvor/Source: Statistički ljetopis, 2008. i 2018.

Pšenica, koja je najvažnija krušna žitarica, u razdoblju od 2003. do 2017. godine bilježi vrlo blagi trend opadanja zasijanih površina i to naročito u zadnje četiri promatrane godine. lako su prosječne površine u ispitivanom razdoblju iznosile 162.976 ha, u 2017. je bilo zasijano svega 116.150 ha što su rekordno niske vrijednosti. Glavni razlozi smanjivanja su zasigurno niske otkupne cijene pšenice i neizvjesnost formiranja cijene što ovu kulturu čini sve manje zanimljivom ratarima. Zanimljivo je kako površine pod pšenicom otprilike svake dvije do tri godine rastu nakon čega se vrate na prosječnih oko 150.000 ha (Graf 2.). U Hrvatskoj se u petnaestogodišnjem razdoblju prosječno proizvelo $788.856 \mathrm{t}$ zrna što je dovoljno za potrebe naše države. Kao i kod kukuruza utvrđena su vrlo velika variranja ostvarene proizvodnje između godina. Tako je najmanje pšenice od svega oko 0,5 milijuna tona proizvedeno 2003., dok je čak dvostruko veća proizvodnja utvrđena 2009. (936.076 t), 2012. (999.681 t), 2013. (998.940 t) i 2016. (960.081 t) godine. S obzirom da je unatrag nekoliko godina Ministarstvo poljoprivrede donijelo prvo Kodeks otkupa žitarica i uljarica, a kasnije i Pravilnik o parametrima kvalitete i kvalitativnim klasama pšenice u otkupu pšenice (NN 46/2018.), poljoprivredni proizvođači će osim postizanja visokih prinosa veliku pozornost morati posvetiti i kvaliteti, naročito u pogledu sadržaja proteina koja je najznačajniji parametar kada je u pitanju otkup pšenice i posljedično formiranje cijene. Navedeno je moguće postići na nekoliko načina pri čemu sorta, agrotehnika (ponajviše mineralna gnojidba) i godina (vremenske prilike) imaju najznačajniju ulogu. Prosječan prinos pšenice u RH za razdoblje 2003. - 2017. godine iznosio je 4,8 tha ${ }^{-1}$ uz variranja od 3,2 t ha ${ }^{-1}$ u 2003. do 5,9 t ha $^{-1}$ u 2017. godini, što je za oko $84 \%$ više. Međutim, u većini promatranih godina ostvaren prinos je bio bolji od prosjeka što znači kako je utjecaj vremenskih prilika na prinos pšenice puno manji jer se radi o ozimoj kulturi koja nije toliko izložena utjecajima nedostatka oborina i visokih temperatura. 


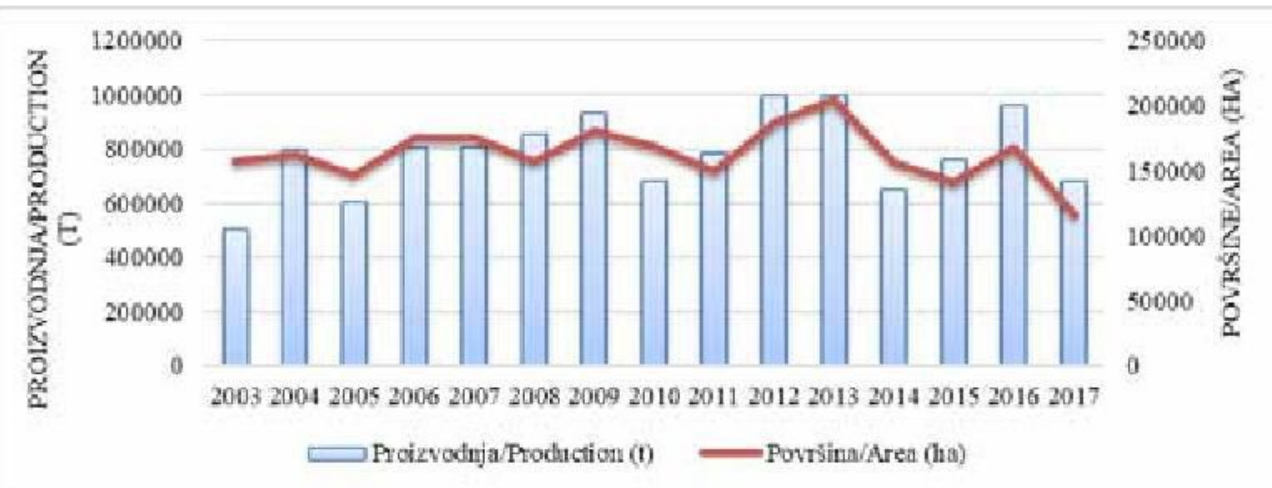

Graf 2. Požnjevene površine (ha) i proizvodnja (t) pšenice u Hrvatskoj od 2003. do 2017. Graph 2. Harvested area (ha) and wheat production in Croatia from 2003 to 2017 Izvor/Source: Statistički ljetopis, 2008. i 2018.

Tendenciju opadanja zasijanih površina ima i ječam (Graf 3.). U promatranom razdoblju (2003. - 2017.) nalazi se na četvrtom mjestu po površinama što nije bio slučaj prije, dok je po proizvodnji ipak na trećem mjestu. U Hrvatskoj se prosječno uzgajao na 55866 ha uz variranja od 43.700 ha (2015.) do 67.538 ha (2004.). Najviše ječma (preko 65.000 ha) je bilo zasijano 2003., 2004. i 2008. godine, dok je 2011., 2014. i 2015. godine bilo najmanje zasijanog ječma, prosječno oko 46.000 ha. U pogledu proizvodnje ječma u Hrvatskoj, prosječno se proizvelo 214.643 $\mathrm{t}$ ječma uz variranja od 160.203 t (2003. godine) do 279.106 t (2008. godine), iz čega proizlazi da razlike u proizvodnji mogu biti i do $43 \%$, što je izuzetno veliko variranje. U promatranom petnaestogodišnjem razdoblju, $u$ čak šest različitih godina ostvareno je manje od $200.000 \mathrm{t}$ dok je u preostalih devet to bilo iznad navedene vrijednosti. Prosječan ostvaren prinos ječma u promatranom razdoblju je bio 3,9 t ha-1 uz variranja od 2,5 t ha-1 u 2003. do 4,8 $\mathrm{t} \mathrm{ha}^{-1} \mathrm{u} 2017$. što čini razliku od čak $92 \%$ više.

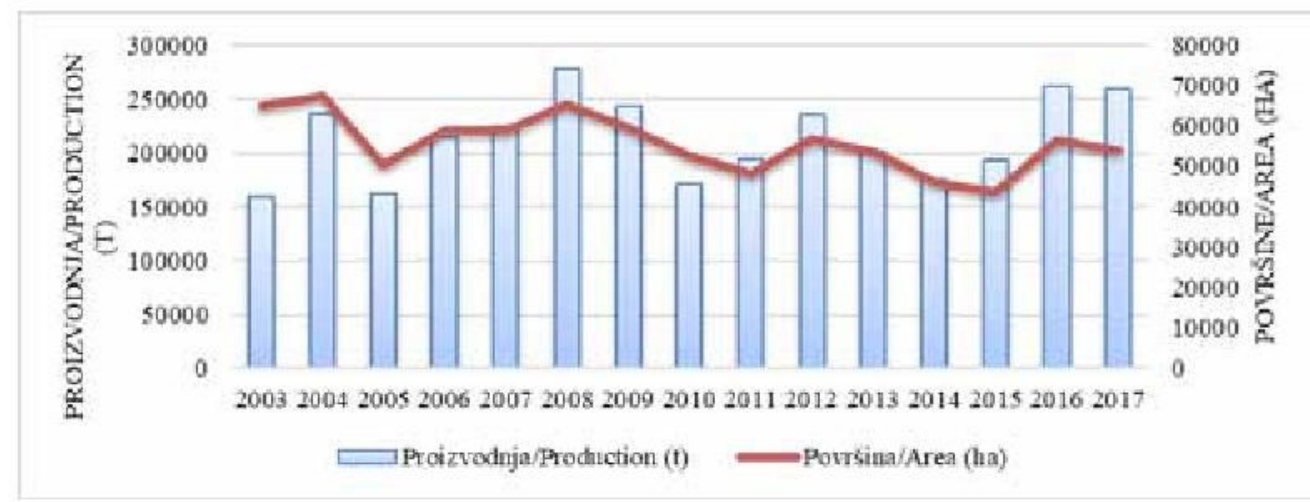

Graf 3. Požnjevene površine (ha) i proizvodnja (t) ječma u Hrvatskoj od 2003. do 2017. Graph 3. Harvested area (ha) and barley production in Croatia from 2003 to 2017 Izvor/Source: Statistički ljetopis, 2008. i 2018. 
U usporedbi sa žitaricama, uljarice, a naročito soja i uljana repica (Grafovi 4. i 6.) imaju tendenciju rasta proizvodnih površina. Naše najznačajnije uljarice su soja, suncokret i uljana repica. Soja se prosječno (2003. - 2017.) uzgajala na 56.052 ha, čime se nalazi na trećem mjestu po veličini proizvodnih površina u Hrvatskoj, nakon kukuruza i pšenice, a ispred ječma. Do ovog rangiranja je došlo zahvaljujući izuzetno velikom povećanju zasijanih površina sojom u 2015., 2016. i 2017. godini od čak 41\% u usporedbi s petnaestogodišnjim prosjekom (2003. - 2017.). Povećanje proizvodnih površina soje može se promatrati s više aspekata. Potrošačke preferencije zasigurno su jedan od razloga, a drugi razlog može biti Zajednička poljoprivredna politika koja proizvođaču omogućava veću proizvođačku cijenu (Salamon i sur., 2017.). Jedan od razloga je vjerojatno i uvođenje novih mjera potpore poljoprivredne proizvodnje koje provodi Agencija za plaćanja u poljoprivredi, ribarstvu i ruralnom razvoju kroz «Zelena plaćanja» za vremensko razdoblje od 2015. - 2020. godine (NN 21/2019.). Prema mjerama «Zelenih plaćanja» jedan od uvjeta je poštivanje raznolikosti usjeva, održavanje ekološki značajnih površina i očuvanje trajnih travnjaka. Osim toga, uslijed relativno sigurnog otkupa sjemena soje, mnogi poljoprivrednici se odlučuju upravo na proizvodnju soje. Osim redovitih rokova sjetve, postrna sjetva soje se sve češće primjenjuje u praksi, što dakako pridonosi povećanju proizvodnje soje u Hrvatskoj. Prosječna proizvodnja zrna soje je iznosila 138.418t (2003. - 2017. godine), uz najveća variranja od svih ispitivanih ratarskih usjeva. Najmanje soje je proizvedeno 2003., svega 82.591 t, dok je najviše proizvedeno u 2016., čak 244.075 t što čini razliku od 161.484 t. Samo u četiri analizirane godine (2003., 2004., 2007. i 2012.) od kojih su u tri bile izuzetno nepovoljne za uzgoj soje ostvarena proizvodnja soje je bila manja od $100.000 \mathrm{t}$. Općenito, prosječan prinos soje $\mathrm{u}$ analiziranom periodu je iznosio $2,5 \mathrm{t} \mathrm{ha}^{-1}$.

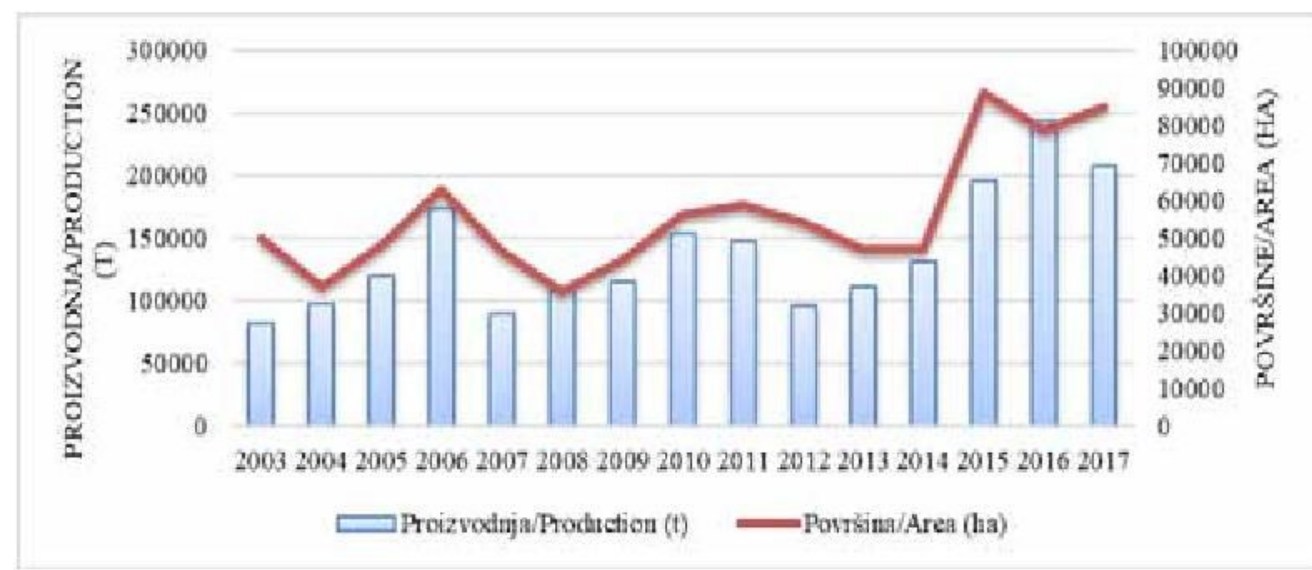

Graf 4. Požnjevene površine (ha) i proizvodnja (t) soje u Hrvatskoj od 2003. do 2017. Graph 4. Harvested area (ha) and soybean production in Croatia from 2003 to 2017 Izvor/Source: Statistički ljetopis, 2008. i 2018.

Suncokret i uljana repica su pored soje naše najznačajnije uljarice i po zasijanim površinama se nalaze na petom i šestom mjestu u ratarskoj proizvodnji. Najvećim dijelom se u Hrvatskoj suncokret uzgaja u istočnim područjima koje karakteriziraju povoljniji vremenski uvjeti za njegov uzgoj za razliku od drugih dijelova zemlje. Suncokret se prosječno uzgajao na 33.719 ha (2003. - 2017.) uz značajno variranje površina do 2008. godine, nakon čega je njegova krivulja 
imala blagi jednolični rast (Graf 5.). U analiziranom razdoblju prosječno se proizvelo $89.431 \mathrm{t} \mathrm{uz}$ variranja od 54.303 t u 2007. do 130.576 t u 2013. godini. Najniža ostvarena proizvodnja u 2007. godini, proizlazi iz toga što je te godine zasijano najmanje površina pod suncokretom, odnosno svega 20.615 ha. Prosječni prinosi suncokreta u Hrvatskoj (2003. - 2017. godine) iznose 2,7 $\mathrm{t} \mathrm{ha}^{-1}$, uz najveća variranja između godina od $1,6 \mathrm{t} \mathrm{ha}^{-1} \mathrm{u} 2005$. do 3,2 $\mathrm{t} \mathrm{ha}^{-1} \mathrm{u} 2013$., što čini razliku od čak $100 \%$ što je u usporedbi sa svim drugim ispitivanim usjevima najveći postotak. Drugim riječima, suncokret je po pitanju prinosa najvarijabilnija kultura na koju vremenske prilike imaju izuzetan značaj (Jug i sur., 2018.). Zbog dobro razvijenog korijenovog sustava suncokret može dati zadovoljavajuće prinose i u sušnim godinama. Jedan do glavnih nedostatka pri uzgoju suncokreta je taj što suncokret napada veći broj bolesti koje se češće javljaju u godinama s više oborina. Premda u Hrvatskoj ima domaćih hibrida suncokreta, potrebno je stvoriti hibride koji bi bili prilagođeni različitim uzgojnim područjima kako bi se njegova proizvodnja proširila.

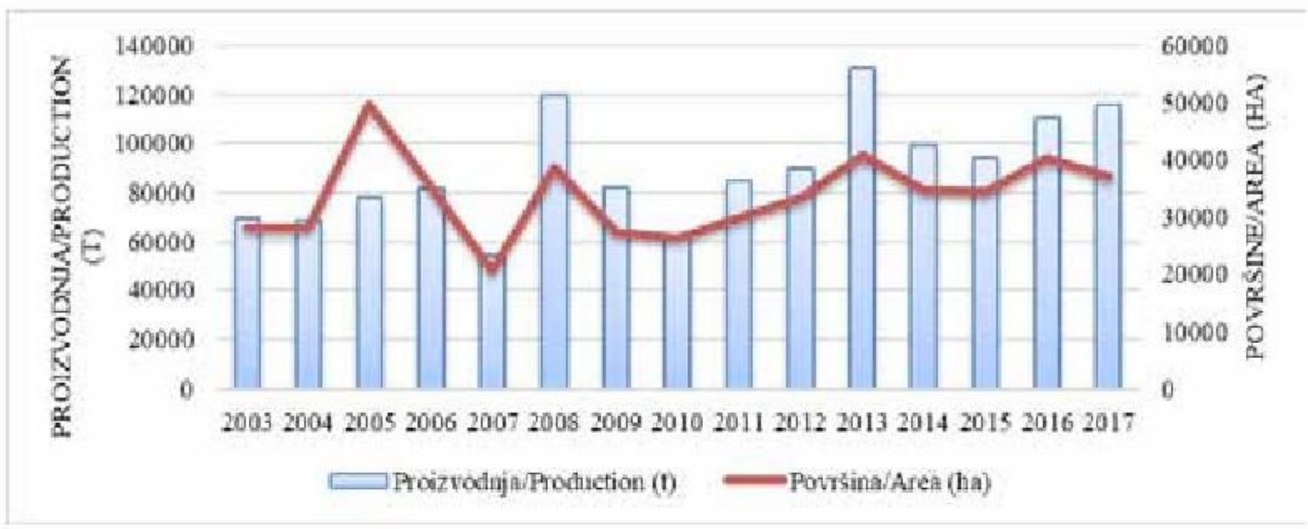

Graf 5. Požnjevene površine (ha) i proizvodnja (t) suncokreta u Hrvatskoj od 2003. do 2017. Graph 5. Harvested area (ha) and sunflower production in Croatia from 2003 to 2017 Izvor/Source: Statistički ljetopis, 2008. i 2018.

Pozitivni trend rasta uzgoja na našim oranicama ima i uljana repica (Graf 6.). lako se prosječno uzgaja na svega 20.986 ha (2003. - 2017.), u 2016. i 2017. godini su površine pod ovom kulturom gotovo udvostručene, a rane procjene za 2018. govore o rekordnim površinama pod ovom kulturom od čak 53.000 ha (DZS, 2018.). Treba napomenuti kako se vrijednosti odnose na površine pod uljanom repicom koje nisu namijenjene za proizvodnju biodizela. Najmanje površine ispod 10.000 ha su zabilježene samo u dvije godine (2006. 8413 ha i 2012. 9893 ha). Po ostvarenoj proizvodnji od prosječno 55.835 t uljana repica se nalazi na šestom mjestu uz vrlo velika odstupanja između godina. Najčešći razlog ovako velikom variranju zasijanih površina je u roku sjetve koji je u našim uvjetima od 25. kolovoza do 10. rujna. Ukoliko su u tom razdoblju sušni uvjeti, mnogi proizvođači odustaju od sjetve uljane repice. Najčešće iz toga razloga nastaju velika variranja u veličini zasijanih površina u Hrvatskoj (Pospišil i sur., 2014.). Prosječni prinosi sjemena uljane repice u Hrvatskoj iznose $2,6 \mathrm{t} \mathrm{ha}^{-1}(2003$. - 2017.) uz variranja od 1,8 $t$ ha $^{-1}$ u 2003. do $3,1 \mathrm{t} \mathrm{ha}^{-1}$ u 2014. i 2016., što predstavlja razliku od $72 \%$. 


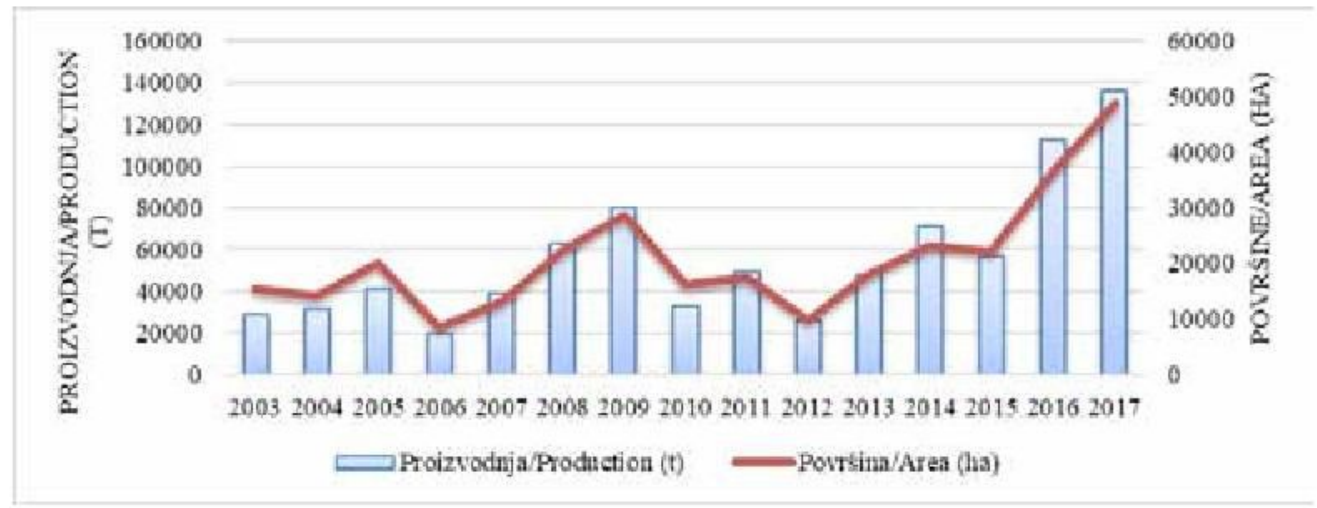

Graf 6. Požnjevene površine (ha) i proizvodnja (t) uljane repice u Hrvatskoj od 2003. do 2017.

Graph 6. Harvested area (ha) and rapeseed production in Croatia from 2003 to 2017 Izvor/Source: Statistički ljetopis, 2008. i 2018.

Vanjskotrgovinska razmjena žitarica i uljarica u razdoblju od 2003. do 2017.

Porast volumena biljne proizvodnje u ukupnoj strukturi poljoprivredne proizvodnje nakon ulaska Hrvatske u Europsku uniju posljedica je, između ostalog značajnih promjena ekonomskog okruženja u kojem se trenutno proizvođači nalaze (Franić i Ljubaj, 2015., Zrakić, 2016.). S obzirom na pozitivne proizvodne pokazatelje, domaće tržište samodostatno je žitaricama, naročito pšenicom i kukuruzom, a od 2012. godine i ječmom (Zrakić, 2016.). Viškove žitarica Hrvatska izvozi te ostvaruje pozitivne vrijednosti neto izvoza (Graf 7.). Prema podacima Ministarstva poljoprivrede (MP, 2016.) u 2016. godini izvezeno je žitarica u vrijednosti od 150,3 milijuna eura, dok je uvoz iznosio 45,2 milijuna eura te je ostvaren suficit od 105,1 milijuna eura.

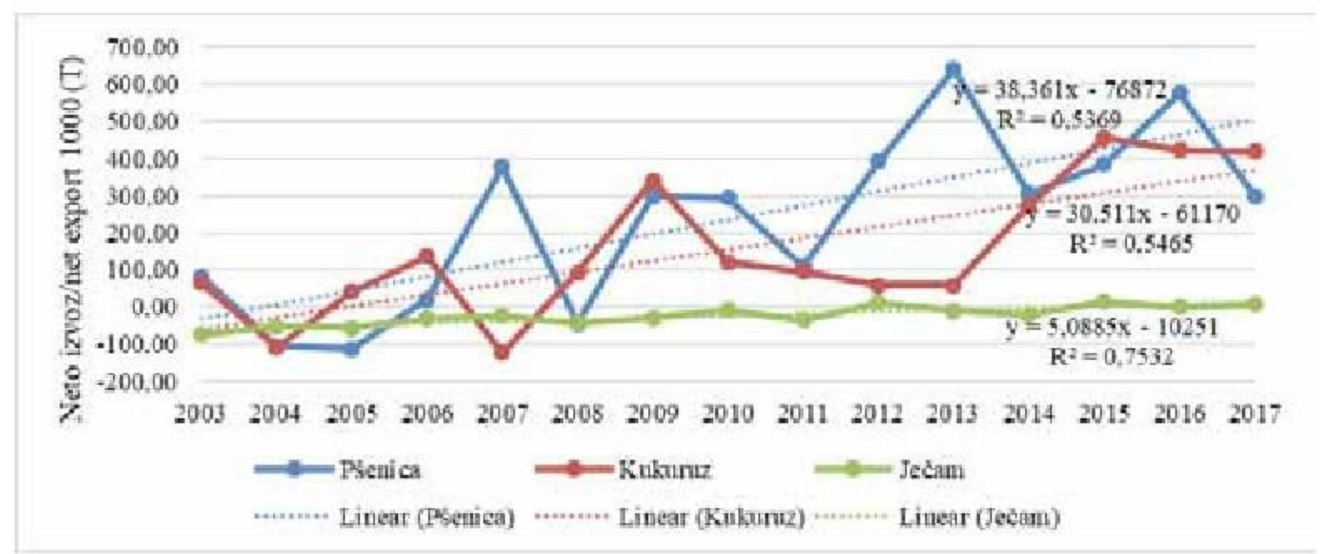

Graf. 7. Neto izvoz pšenice, kukuruza i ječma (t) u RH od 2003. do 2017.

Graph 7. Net exports of soft wheat, corn and barley (t) in Croatia from 2003 to 2017 Izvor: obrada autora prema podatcima DZS i EUROSTATA 2003.-2017. 
Sektor uljarica bilježi snažan rast proizvodnog volumena nakon ulaska Hrvatske u EU pogotovo uljane repice i soje (Kranjac i sur., 2019.). Hrvatska volumenom proizvodnje daleko premašuje domaće potrebe za uljaricama, a zbog ograničenih preradbenih kapaciteta dosta proizvedenog sjemena uljarica se izvozi (Graf 8.) većinom na EU tržište gdje se dalje prerađuju.

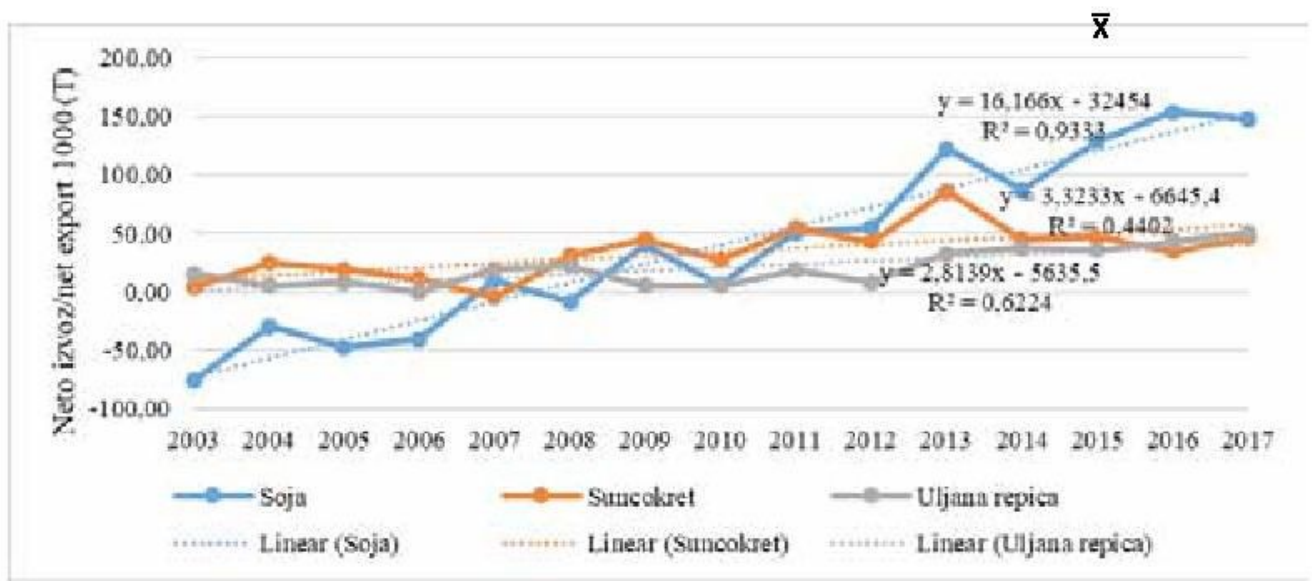

Graf 8. Neto izvoz soje, suncokreta i kukuruza (t) u RH od 2003. do 2017.

Graph 8. Net exports of soy bean, sunflower and rapeseed (t) in Croatia from 2003 to 2017 Izvor: obrada autora prema podatcima DZS i EUROSTATA 2003.-2017.

Od 2013. godine proizvođačke cijene koje prate trendove cijena u EU pozitivno utječu na neto izvoz žitarica. Stabilan razvoj i nešto niža razina prosječnih proizvođačkih cijena u Hrvatskoj od prosječne proizvođačke cijene žitarica i uljarica na zajedničkom tržištu EU, čine domaću proizvodnju cjenovno konkurentom (Zrakić, 2016.).

t Uočljivo je kako uljarice postižu više proizvođačke cijene u promatranom periodu (Graf 9.), čime možemo lako objasniti rast zasijanih površina i volumena proizvodnje uljarica.

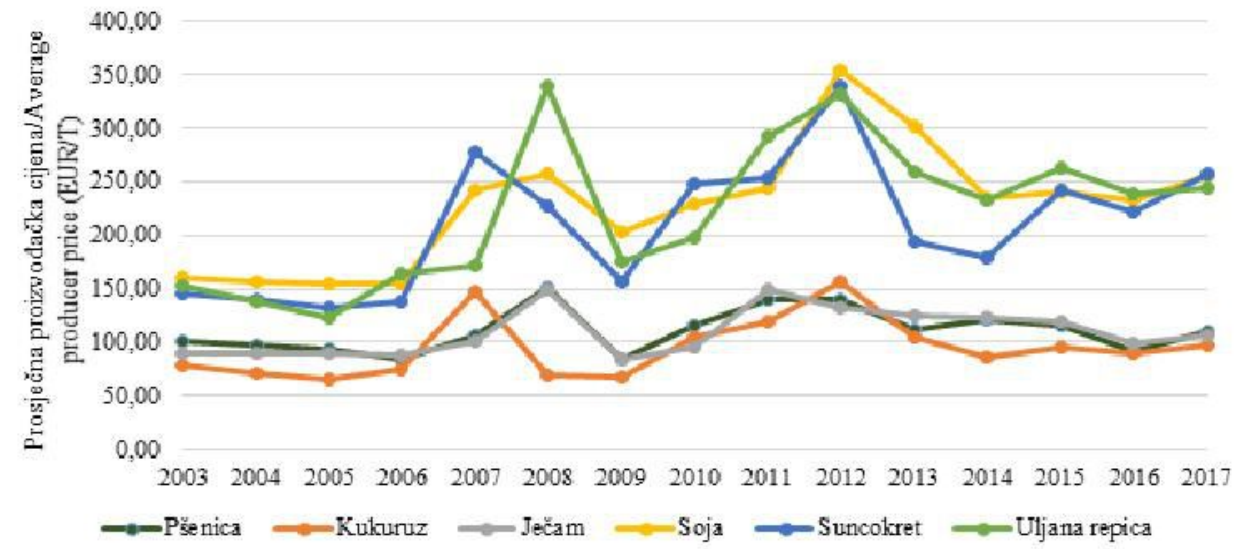

Graf 9. Prosječne proizvođačke cijene žitarica i uljarica (EUR/t) u RH od 2003. do 2017.

Graph 9. Average producer prices of grains and oilseeds (t) in Croatia from 2003 to 2017 Izvor: obrada autora prema podatcima DZS i EUROSTATA 2003.-2017. 
Uvjeti poslovanja na jedinstvenom tržištu i niže domaće cijene u odnosu na prosječne EU cijene omogućuju daljnje jačanje neto izvoza ratarskih kultura. Sličan trend uočen je i kod drugih novih članica (EU 13) gdje biljna proizvodnja ostvaruje pozitivne proizvodne pokazatelje uz status neto izvoznika (Csaki i Jambor, 2009., Csaki i Jambor, 2013.).

\section{Zaključak}

$\mathrm{U}$ analiziranom periodu vidljiv je pad zasijanih površina pod kukuruzom, dok se površine pod uljaricama zadnjih godina povećavaju, posebno pod sojom i uljanom repicom. Razlozi ovakvog trenda su kompleksni, ali treba istaknuti kako su visina i stabilnost otkupne cijene te razina ulaganja u proizvodnju glavni motivirajući čimbenici proizvođača ratarskih kultura. Sa stajališta ostvarenih prinosa po hektaru najveće varijacije u promatranom razdoblju su uočene kod suncokreta od čak $100 \%$, zatim ječma $(92 \%)$, pšenice $(84 \%)$, soje $(82 \%)$ i kukuruza $(80 \%)$ dok je variranje prinosa između godina najmanje kod uljane repice (72\%). S ekonomskog stajališta, tržišta žitarica i uljarica bilježe pozitivne proizvodne pokazatelje u Europsk $\bar{\jmath}$ Uniji posebno u državama članicama EU 13. Republika Hrvatska je i prije pristupanja EU bila samodostatna i neto izvoznica glavnih ratarskih kultura uglavnom pšenice i kukuruza, a nakon pristupanja EU pozitivni trendovi biljne proizvodnje su osnaženi uvjetima poslovanja na jedinstvenom tržištu te instrumentima i mjerama Zajedničke poljoprivredne politike. Trenutno Republika Hrvatska ima status neto izvoznice triju najvažnijih žitarica i uljarica. Nakon pristupa Hrvatske u EU u ukupnoj strukturi neto izvoza prevladavaju kukuruz $(42,4 \%)$ i pšenica $(57,5 \%)$, odnosno soja $(58,2 \%)$, suncokret $(23,5 \%)$ i uljana repica $(18,2 \%)$. S obzirom na stabilnu i relativno značajnu potražnju žitarica i uljarica na EU tržištu za očekivati je daljnje jačanje neto izvoza. Navedeno potkrjepljuju stabilne domaće proizvođačke cijene koje su u prosjeku niže od prosječnih EU proizvođačkih cijena, čineći domaći sektor biljne proizvodnje cjenovno konkurentnim.

\section{Literatura}

Csáki, Cs., Jámbor, A. (2009) The Diversity of Effects of EU Membership on Agriculture in New Member States, Policy Studies on Rural Transition No. 2009-4. Budapest: FAO Regional Office for Europe and Central Asia. 3-40.

Csáki, Cs., Jámbor, A. (2013) The impact of EU accession: lessons from the agriculture of the new member states, Post-Communist Economies, 25 (3): 325-342. DOI: 10.1080/14631377.2013.813139

EUROSTAT baze podataka za poljoprivredu 2018. URL: https://ec.europa.eu/eurostat/data/database (08.03.2019.).

Franić, R. i Ljubaj, T. (2015) Common Agriculture Policy: The Case of Croatia. U: Lajh, D., Petak, Z. ur. EU Public Policies Seen from a National Perspective: Slovenia and Croatia in the European Union. Ljubljana, Slovenija, Faculty of Social Sciences, 141-152.

Husnjak, S. i Bensa, A. (2018) Pogodnost poljoprivrednog zemljišta za navodnjavanje u agroregijama hrvatske, Hrvatske vode, 26 (105), 157-180.

Jug., D., Jug , I., Brozović, B., Vukadinović, V., Stipešević, B., Đurđević, B. (2018) Uloga konzervacij ske poljoprivrede u ublažavanju i prilagodbi klimatskim promjenama. Poljoprivreda 24 (1), 35-44. DOI: 10.18047/poljo.24.1.5

Kranjac, D., Zmaić, K., Sudarić, T., Grgić, I., Zrakić, M. (2019) Pregled i perspektive tržišta soje u Republici Hrvatskoj do 2030. godine primjenom modela parcijalne ravnoteže. U: Mioč, B., Širić, I. ur. Zbornik radova 54. hrvatski i 14. međunarodni simpozija agronoma, Vodice, Hrvatska, 17.-22. 02. 2019., Agronomski fakultet Zagreb, 127-131.

Matić, S., Tomić, F., Anić, I. (2015) Proizvodnja hrane i šumarstvo-temelj razvoja istočne Hrvatske, Hrvatska akademija znanosti i umjetnosti, Zagreb.

Ministarstvo poljoprivrede. Hrvatska poljoprivreda 2016. u brojkama. URL: http://www.mps.hr/datastore/filestore/140/Hrvatska poljoprivreda 2016.pdf (14.3.2019.)

Narodne novine. Pravilnik o parametrima kvalitete i kvalitativnim klasama pšenice u otkupu pšenice roda 2018. godine, NN 46/2018, URL: https://narodne-novine.nn.hr/clanci/sluzbeni/2018_05_46_881.html (22.3.2019.)

Narodne novine. Pravilnik o provedbi izravne potpore poljoprivredi i iaks mjera ruralnog razvoja za 2019. godinu. NN 21/2019, URL: https://narodne-novine.nn.hr/clanci/sluzbeni/2019_03_21_439.html (25.3.2019.)

Priopćenje. Rane procjene površina važnijih usjeva u 2018. Državni zavod za statistiku. Zagreb. URL: https://www. dzs.hr/Hrv_Eng/publication/2018/01-01-15_01_2018.htm (08.3.2019.).

Program izravnih plaćanja u poljoprivredi 2015 . - 2020. godine, URL: https://www.savjetodavna.hr/adminmax/ publikacije/Zeleno_placanje195.pdf (26.3.2019.)

Pospišil, M., Brčić, M., Pospišil, A., Butorac, J. (2014) Prinos i komponente prinosa istraživanih hibrida i sorata uljane repice. Poljoprivreda, 20 (1), 3-9.

Salamon, P., Banse, M., Barreiro-Hurlé, J., Chaloupka, O., Donnellan, T., Erjavec, E., Fellmann, T., Hanrahan, K., Hass, M., Jongeneel, R., Laquai, V., van Leeuwen, M., Molnár, A., Pechrová, M., Salputra, G., Baltussen, W., Efken, J., Hélaine, S., Jungehülsing, J., von Ledebur, O., Rac, I. and Santini, F. (2017) Unveiling diversity in agricultural markets projections: from EU to Member States. A medium-term outlook with the AGMEMOD model. JRC Technical Report. Publications Office of the European Union, Luxembourg. DOI: 10.2760/363389

Statistički ljetopis Republike Hrvatske (2018) Državni zavod za statistiku Republike Hrvatske. Zagreb, URL: https:// www.dzs.hr/Hrv_Eng/ljetopis/2018/sljh2018.pdf 
Statistički ljetopis Republike Hrvatske (2008) Državni zavod za statistiku Republike Hrvatske. Zagreb, URL: https:// www.dzs.hr/Hrv_Eng/ljetopis/2008/PDF/00-sadrzaj.pdf

Segota, T. i Filipćić, A. (2003) Köppenova podjela klima i hrvatsko nazivlje, Geoadria, 8(1): 17-37.

Zrakić, M. (2016) Model parcijalne ravnoteže ratarske proizvodnje u Hrvatskoj. Doktorska disertacija. Zagreb: Sveučilište u Zagrebu, Agronomski fakultet.

Prispjelo/Received: 1.4.2019.

Prihvaćeno/Accepted: 6.5.2019.

\section{Conditions and perspective of cereals and oilseed crops production in the Republic of Croatia}

\section{Abstract}

Agricultural production in Croatia has great significance whereby plant production makes more than 50\% of total agricultural gross production. The most important role have cereals and oilseeds crops whose production dominates in the Pannonian region with an emphasis on its eastern part. Aim of this study was to shown harvested area, production and foreign trade of six most important field crops during fifteen-year period (2003 - 2017) in Croatia. During analysed period cereals (maize, wheat and barley) occupies about 60 $\%$ while oilseed crops (soybean, sunflower and rapeseed) about $13 \%$ of total arable land. Analysis of the data showed a trend of decline in cereal's harvested area, especially for maize, while oilseeds showed a growth trend. Soybean and rapeseed areas almost doubled in the last three years. The accession of the Republic of Croatia to the unique European Union market has had a positive effect on the increase in net exports of cereals and oilseeds. The average volume of net exports of cereals and oilseeds for five years of EU membership has more than tripled compared to the average of the pre-accession period observed from 2003 to 2013. Domestic prices of cereals and oilseeds follow price trends on the Single Market with stabile development after Croatia joins the European Union.

Keywords: agricultural area, cereals, oil crops, prices, net exports

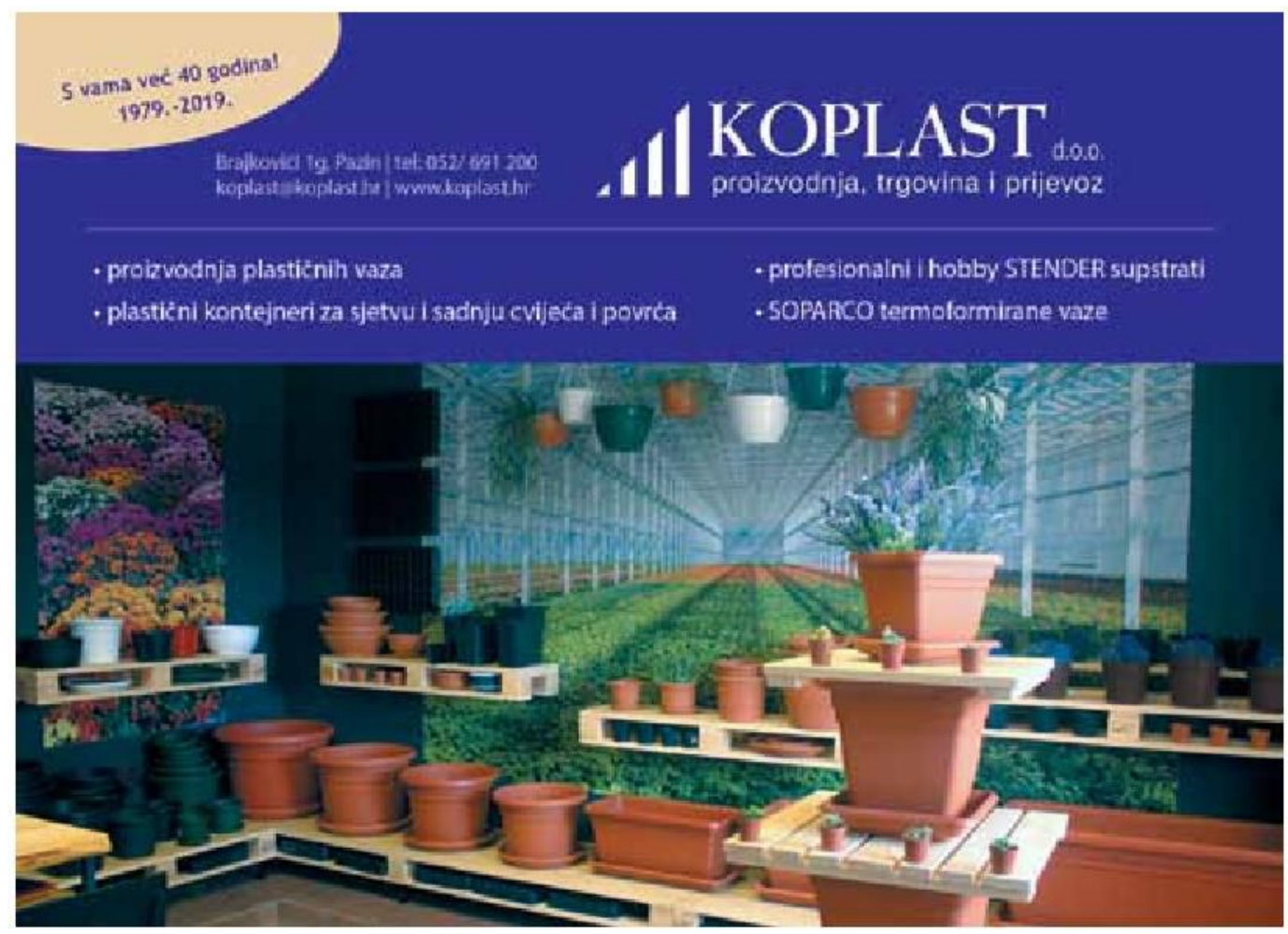

